\title{
CARDIAC OUTPUT AND BLOOD VOLUME IN SEVERE HOOKWORM ANÆMIA
}

\author{
BY \\ MAHMOUD A. JALILI AND ALI Y. HINDAWI \\ From the Department of Medicine of the University of Baghdad, and the Radioisotope Department, Republic Hospital, \\ Baghdad, Iraq \\ Received December 12, 1961
}

The determination of cardiac output has been rendered easy and safe by the introduction of the method using radio-iodinated human serum albumin (IHSA) in conjunction with a suitable external counting system set up over the heart (Veall et al., 1954). Cardiac output is known to be increased in the presence of anæmia (Starr et al., 1934; Sharpey-Schafer, 1944; Brannon et al., 1945), but no work has been done to show the changes in cardiac output and blood volume with the improvement of anæmia. The present paper shows that the blood volume is diminished in hookworm anæmia and that the increased cardiac output is lowered again with improvement of the anæmia.

\section{SubJeCtS AND Methods}

Thirty patients between 15 and 60 years (average $25 \cdot 5 \pm 11$ ) were examined and all had iron deficiency anæmia due to ankylostomiasis. The hæmoglobin in all cases was below $7 \mathrm{~g} .100 \mathrm{ml}$., with an average of $4.56 \mathrm{~g} . / 100 \mathrm{ml}$. The packed cell volume ranged between 12.9 and 34.7 per cent with an average of $24.9 \pm 6.0$ per cent. Two other healthy subjects were examined and two others have recovered from anæmia and attained normal hæmatological values with a packed cell volume between 42 and 50 per cent; their ages ranged between 18 and 30 years. In all there were 33 men and 1 woman.

The test was repeated after the administration of an anthelmintic (alcopar) and iron therapy in 10 cases; in 3 it was repeated twice and in 1 three times at intervals of a few weeks.

I131-labelled human serum albumin was used in conjunction with an external counting system set up over the præcordium. Various workers have found that this method is capable of a high degree of reproducibility in human subjects (Zipf et al., 1957), and many authors state that it compares favour'ably with the Fick method (Huff et al., 1955; Shackman, 1958; Schreiner et al., 1959; Seldon et al., 1959; Gorlin et al., 1959; Sharpe and Shapiro, 1961). Other workers have found it agrees well with results obtained by sampling from a peripheral artery (Pritchard et al., 1955; Mack et al., 1957; Feer et al., 1958). It is clear that the isotope method is superior to the Fick method in that examinations can be done twice weekly on the same person without exceeding the maximum permissible radiation dose for one week or the radiation administered during one cardiac catheterization (Veall and Vetter, 1958).

The gradual breakdown of the iodinated serum albumin in the body will free the labelled radioiodine: thus before the test is done the patient is given $2 \mathrm{~g}$. potassium iodide daily for at least one day before and three days after the test, in order to block the uptake of radio-iodine by the thyroid gland. The fasting patient is given $0 \cdot 1 \mathrm{~g}$. sodium nembutal, and two hours later the blood pressure is recorded. The patients lie on a couch for 30 minutes and to alleviate anxiety they are assured of the simplicity of the procedure. They are also told not to move during the test and not to hold their breath as is the practice in chest X-ray examination; in certain instances this has been the cause 
of failure to obtain good curves. The counter is placed over the third left intercostal space close to the sternal border in long chest subjects and over the second left space in subjects with short and broad chests. The aperture of the collimator is placed $1 \mathrm{~cm}$. from the skin of the bare chest. The counter is fitted with a sodium iodide crystal $(3.2 \mathrm{~cm}$. in diameter). A high degree of collimation is attained by the use of a lead collimator having a cylindrical aperture $2.5 \mathrm{~cm}$. in diameter and $7 \mathrm{~cm}$. deep. The counter is connected to a recording ratemeter (type 1418 A developed at A.E.R.E., Harwell, and specially designed for such isotope measurements). The standard used is $5 \mathrm{ml}$. of 1 in 2000 dilution of the injected iodinated albumin solution. At first a count rate range of 1000 counts per second was used, but it was found that better curves were obtained when the count rate range was changed to 300 counts per second. The loss in accuracy is compensated for by the high degree of collimation attained with a collimator $7 \mathrm{~cm}$. deep. The time constant used is $0.5 \mathrm{sec}$. for recording the time concentration curve and $10 \mathrm{sec}$. for the calibration measurement. An accurately known volume, 1.0 or $1.5 \mathrm{ml}$., of the iodinated human serum albumin solution is injected smoothly and rapidly into the right antecubital vein. It was found by Gunnells and Gorten (1961) that when IHSA was injected in a volume of $1.5-2 \mathrm{ml}$. into an antecubital vein, the values for cardiac output calculated by external counting were similar to values obtained by arterial sampling of the Evans blue dye injected into the superior vena cava. The injection is made with a high-grade calibrated syringe with a 19-20 S.W.G. gauge needle, and the time signal is pressed on the chart recorder which is already running. At the same time the pulse is counted for 30 seconds which covers the period during which the whole concentration curve is recorded on the chart. The chart recorder is then stopped. After allowing 10 minutes for complete mixing, the equilibrium counting rate is recorded on the chart, and at the same time $10 \mathrm{ml}$. of blood are taken from the left arm. The activity of the blood sample after hæmolysis with saponin is compared with that of the standard by taking $5 \mathrm{ml}$. of each in identical containers and placing the containers in the collimated aperture with the counter inverted. In five instances the activity of 3-ml. samples of blood and standard was determined in a well-type scintillation counter, and the values of the calculated cardiac output were similar to those obtained when the inverted counter was used for the measurement of the activity.

The height and weight are recorded for the calculation of the surface area using the nomogram of Boothby and his associates which is based on the DuBois formula (Gibson and Evans, 1937).

The radio-iodinated human serum albumin was obtained from the Radiochemical Centre, Amersham, in weekly shipments by air.

\section{Calculation}

The cardiac output is calculated on the basis of the Stewart-Hamilton formula using the following equation adopted by Veall and Vetter (1958):

$$
\text { Cardiac output }=\frac{E \times S \times D \times I \times C}{10^{3} \times A \times B} 1 . / \mathrm{min} .
$$

where $E$ is the height of the equilibrium plateau; $A$, the area under single passage time-concentration curve; $S$, the counting rate of the standard; $B$, the counting rate of the blood sample; $D$, the dilution factor of the standard; $I$, the volume of solution injected (ml.); and $C$, the chart speed.

The units for measuring the data can be quite arbitrary. An accurate, easy, and quick method of calculation is suggested by $\mathrm{N}$. Veall (personal communication) where the units for measurement are the chart divisions. Thus $E, S$, and $B$ can be measured in vertical chart divisions and $A$ measured in terms of rectangles on the chart. The time is measured in horizontal chart divisions and therefore $C$ is expressed in chart divisions per minute, which in our setting is 48 divisions per minute. A horizontal line is drawn across each time division to represent the mean counting rate during that interval. The readings of these horizontal lines are put on semilog paper, and a straight line is drawn through the points that represent the descending logarithmic portion of the left heart curve. The point at the beginning of this line is read and when this reading is multiplied by the half period of the semilog 
curve and the constant 1.44 (which converts half period into average period), the result in rectangles will be the area under the descending limb of the curve had it reached the baseline without the effect of recirculation. To this is added arithmetically the readings of the rectangles under the rest of the curve (Fig. 1).

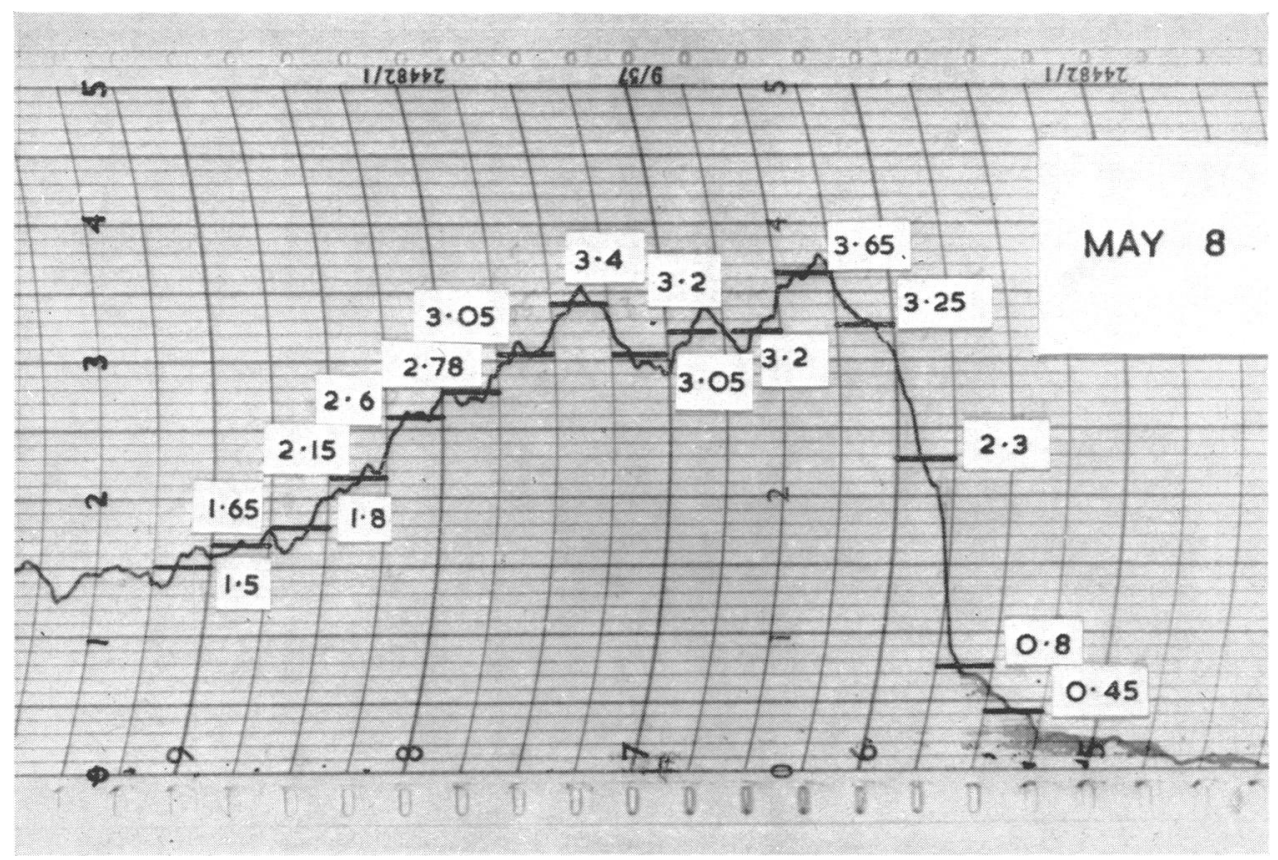

FIG. 1.-An isotope dilution curve showing the method of calculation.

To calculate the blood volume the packed cell volume (P.C.V.) is determined. The heparinized blood sample is centrifuged at 3000 r.p.m. for 30 minutes in a hæmatocrit tube, and the reading is corrected for trapped plasma according to Chaplin and Mollison (1952). This was done twice. The plasma volume is calculated according to the following formula.

Plasma volume $=\frac{S \times D \times I}{10^{5} \times B}(100-H)$ litres, where $S, D, I$, and $B$ have the same values used for the calculation of cardiac output, and $H$ is the venous hæmatocrit corrected for trapped plasma.

The blood volume is then calculated from the plasma volume as follows.

$$
\text { Blood volume }=\frac{\text { Plasma volume }}{100-\mathrm{WBH}} \times 100 \text { litres, }
$$

where WBH (whole body hæmatocrit) is obtained by multiplying the observed venous hæmatocrit by the factor 0.91 (Chaplin, Mollison, and Vetter, 1953).

The teleradiogram of the heart of many patients was studied, and the frontal area and heart volume were measured. The following formula for the frontal cardiac area was used.

$$
A=\frac{\pi}{4} \times \text { long diameter } \times \text { broad diameter. }
$$

The formulæ for the heart volume were as follows.

$V=0.36$ long $\times$ broad $\times$ transverse diameters, and $V=0.63$ broad $\times$ long $\times$ sagittal diameters (Ungerleider and Gubner, 1942; Nylin, 1957). 


\section{RESULTS AND DiscusSion \\ The Blood Volume}

Storaasli et al. (1950) used IHSA for determination of blood volume with satisfactory results: the average plasma volume was $40 \cdot 3 \pm 4 \cdot 2 \mathrm{ml} / \mathrm{kg}$. body weight. The T-1824, $\mathrm{I}^{131} \mathrm{albumin}$, and the antigen and hæmoglobin methods gave comparable values of plasma volume of $45 \mathrm{ml} / \mathrm{kg}$. (Gregersen and Rawson, 1959). In the present work the plasma volume was $50.8 \mathrm{ml} / \mathrm{kg}$. but was greatly increased in anæmic subjects, being $64.9 \mathrm{ml} . / \mathrm{kg}$. which is a well-known compensatory mechanism in the presence of anæmia.

It is clear from Table I that the blood volume and plasma volume of healthy subjects calculated per unit of surface area and height do not show large variations in different series. However when the values are calculated per $\mathrm{kg}$. of body weight there are marked variations between groups of healthy subjects. This is due to the fact that there is a difference between the blood volume in lean and

TABLE I

Plasma and Blood Volume in Men

\begin{tabular}{|c|c|c|c|c|c|c|c|c|c|}
\hline & & \multicolumn{4}{|c|}{ Plasma volume } & \multicolumn{4}{|c|}{ Blood volume } \\
\hline & & Litres & $\begin{array}{l}1 . / \mathrm{m} .2 \\
\text { (area) }\end{array}$ & $\begin{array}{l}1 . / 100 \mathrm{~cm} . \\
\text { (height) }\end{array}$ & $\begin{array}{l}\text { ml./kg. } \\
\text { (weight) }\end{array}$ & Litres & $\begin{array}{l}1 . / \mathrm{m} .2 \\
\text { (area) }\end{array}$ & $\begin{array}{l}\text { 1. } / 100 \mathrm{~cm} \text {. } \\
\text { (height) }\end{array}$ & $\begin{array}{l}\mathrm{ml} / \mathrm{kg} . \\
\text { (weight) }\end{array}$ \\
\hline \multicolumn{2}{|c|}{ Healthy Subjects: } & & & & & & & & \\
\hline \multicolumn{2}{|c|}{$\begin{array}{l}\text { Present work } \\
\text { Gibson and Evans (1937) }\end{array}$} & 2.97 & 1.78 & 1.76 & $\begin{array}{l}50 \cdot 8 \\
37.5\end{array}$ & $\begin{array}{l}4.94 \\
5.32\end{array}$ & 2.96 & 2.92 & $\begin{array}{l}84 \cdot 3 \\
67.0\end{array}$ \\
\hline \multicolumn{2}{|c|}{ Gregersen (1944) .. . } & 2.70 & 102 & - & 45.0 & - & 2.93 & 3.01 & $0 / .9$ \\
\hline \multirow{2}{*}{\multicolumn{2}{|c|}{$\begin{array}{l}\text { Storaasli et al. (1950) } \\
\text { Berlin } \text { et al }(1950)\end{array}$}} & - & - & - & $40 \cdot 3$ & - & - & - & - \\
\hline & & - & - & - & 38.7 & - & - & - & $68 \cdot 6$ \\
\hline \multicolumn{2}{|c|}{$\begin{array}{c}\text { Bradey et al. (1945) } \\
\text { T-1824 }\end{array}$} & - & - & - & $45 \cdot 4$ & - & - & - & $75 \cdot 5$ \\
\hline \multirow{2}{*}{\multicolumn{2}{|c|}{$\begin{array}{c}\text { Gregersen } \\
(1959)\end{array}$ and Rawson }} & & & & & & & & \\
\hline & & - & - & - & $45 \cdot 6$ & - & - & 一 & $77 \cdot 0$ \\
\hline $\begin{array}{l}\text { Anamic Subjects: } \\
\text { Present work }\end{array}$ & .. & 3.55 & $2 \cdot 22$ & $2 \cdot 13$ & 64.9 & $4 \cdot 59$ & $2 \cdot 87$ & $2 \cdot 76$ & $83 \cdot 8$ \\
\hline
\end{tabular}

obese body tissue (Huff and Feller, 1956; Edwards and Whyte, 1960). In our anæmic patients there is only a slight decrease in the blood volume calculated per $\mathrm{m}^{2}$ or per height, but it looks, when calculated per weight, much higher than the values in normal subjects obtained by others, though lower than our control cases. This is due to the fact that our subjects are thin and this results in high values of blood volume per $\mathrm{kg}$. The weight of our patients ranged between 37 and $69 \mathrm{~kg}$. with an average of $54 \cdot 8 \pm 7 \cdot 2 \mathrm{~kg}$. The height ranged between 145 and $187 \mathrm{~cm}$. with an average of $166.5 \pm 8.9 \mathrm{~cm}$. Our findings are in agreement with the conclusion of Gibson and Evans (1937) that normal values are best estimated from surface areas and from height if marked disturbance in weight exists; and with Perera (1946) who found that volume determinations in underweight persons were higher than the predicted values from surface area. The surface area is also a better reference than the height, and the correlation between the blood volume and the surface area is better as can be seen by examining the chart of Boothby and Sandiford of the Mayo Clinic (published by Gibson and Evans, 1937). The statement of Huff and Feller (1956) and Inkley, Brooks, and Krieger (1955) that the blood volume can well be predicted from body weight is open to criticism. Age has no effect on the blood volume of adults (Cohn and Shock, 1949).

The plasma volume determined in our patients was always high, with an average of $3.55 \pm 0.68$ litres. This is a well-known compensatory mechanism in the presence of anæmia. The calculated blood volume was rather low, the average being 4.59 litres. It is less than the blood volume of 4.94 litres in healthy subjects with a hæmatocrit value over 40 per cent, and an average surface area of $1.67 \mathrm{~m}^{2}$. 
The calculated blood volume was compared with the expected blood volume for that surface area as read from the chart of Boothby and Sandiford. In 16 cases the determined volume was decreased, the average difference being 0.33 ; the biggest difference was 0.9 litre. In another nine cases the determined volume was slightly higher than the expected volume, the average difference being $0 \cdot 35$ litres. In the remaining case there was no difference. The overall average difference in these 26 cases was small, -0.085 litres, but significant ( $t$ test $\mathrm{p}<0.001$ ).

In another two cases with a very small surface area of $1.29 \mathrm{~m} .{ }^{2}$ the blood volume as determined was much higher than the expected volume. The determined values were 3.65 and 3.84 litres and the expected value 2.7 litres. In another two cases with œdema the determined blood volume was also higher than the expected volume being 6.2 and 5.5 litres, and 4.9 and 4.2 litres respectively.

In 10 cases in whom the hæmatocrit increased by more than $20 \mathrm{~mm}$. as the result of the treatment of anæmia, the blood volume was found to be increased $(t$ test $\mathrm{p}<0.001)$. The average increase was $0.50 \pm 0.25$ litres. To correct for the increase in the body weight that occurred in some cases after treatment, the blood volume was calculated per square metre of surface area. The increase in the blood volume per square metre was also significant ( $t$ test $\mathrm{p}<0.01)$, the average increase being $0 \cdot 2 \pm 0 \cdot 201 . / \mathrm{m}^{2}$ The determined blood volume in these cases after recovery was found to be higher than the expected blood volume $(t$ test $\mathrm{p}<0.01)$, the average difference being 0.3 litre.

The blood volume was found to be reduced in chronic anæmia whatever the cause and to increase slowly to normal limits with recovery (Gibson, Harris, and Swigert, 1939): Feldman and Murphy (1945) found it reduced also in anæmia of induced malaria. However this is not generally appreciated, and in a standard monograph on blood diseases (Whitby and Britton, 1957) the blood volume was stated to be lower in idiopathic hypochromic anæmia and in pernicious anæmia, and increased in chlorosis and in anæmia of ankylostomiasis. The last statement was based on the findings of Biggam and Ghalioungui (1934) in Egypt. However, later, Fikri and Ghalioungui (1937) reported that the blood volume was slightly reduced.

\section{Cardiac Output}

The cardiac output in anæmia was always higher than normal (Table II). After treatment with iron and a vermifuge the cardiac output was lowered (Table III). The increase in cardiac output was not associated with an increased pulse rate except in one patient, in whom after improvement of the anæmia the cardiac output came down though the tachycardia persisted. In beri-beri, Blacket and Palmer (1960) found that tachycardia was less important than increased stroke volume in the production of high cardiac output.

In the following discussion the cardiac index will be used rather than the cardiac output for the purpose of comparison between different subjects. The cardiac output was found to be related to the surface area (Taylor and Tiede, 1952), and regardless of the method used for the determination of the cardiac output, it has a positive correlation with the oxygen consumption (Brown and Pearson, 1947). The influence of obesity found by Taylor, Brozek, and Keys (1952) is immaterial in our work because none of our cases was obese and none was muscular. Their weight ranged between 37 and $69 \mathrm{~kg}$. with an average of $54 \cdot 8 \pm 7 \cdot 2 \mathrm{~kg}$.

Fig. 2 shows that there is certain correlation between the cardiac index and the P.C.V. $(r=0.39$; $\mathrm{p}<0.05$ ). The P.C.V. was found to be the better parameter in the present study. When the log of the P.C.V. was related to the $\log$ of the cardiac index, the correlation was almost the same, $r=0.43$. Fig. 3 shows the correlation between the stroke index and the P.C.V. $(r=0.37 ; p<0.05)$; and when the log of the P.C.V. was related to the log of the stroke index the correlation was similar, $r=0 \cdot 40$. The stroke index eliminates the influence of the heart rate. The relationship was found to be linear.

In 1922, Fahr and Ronzone showed that cardiac output was increased in anæmia, as a compensatory mechanism, with a rise in the coronary circulation to the extent seen in severe work. A slight increase of output was found in cases of anæmia with an average hæmoglobin of 50 per cent (Starr et al., 1934), and Brannon et al. (1945) found that the cardiac output increased when the hæmo- 
TABLE II

Cardiac Output and Blood Volume Studies

\begin{tabular}{|c|c|c|c|c|c|c|c|c|c|c|}
\hline 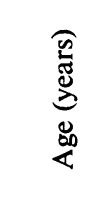 & 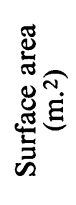 & $\begin{array}{l}0_{0}^{0} \\
\dot{0} \\
\dot{0}\end{array}$ & 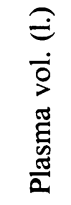 & $\begin{array}{l}\stackrel{0}{\Xi} \\
\stackrel{\Xi}{\circ} \\
\frac{0}{0} \\
\frac{0}{\infty}\end{array}$ & 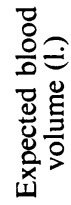 & 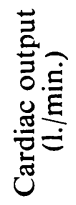 & 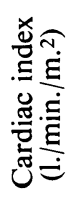 & 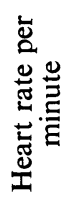 & 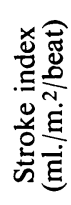 & 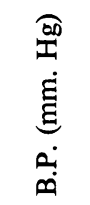 \\
\hline \multicolumn{11}{|c|}{ Anamic patients } \\
\hline 17 & $1 \cdot 29$ & $12 \cdot 9$ & $3 \cdot 24$ & 3.65 & $2 \cdot 7$ & 6.9 & $5 \cdot 4$ & 84 & 64 & $100 / 55$ \\
\hline 38 & $1 \cdot 82$ & $15 \cdot 7$ & 5.03 & $5 \cdot 83$ & $5 \cdot 4$ & $13 \cdot 3$ & $7 \cdot 3$ & 84 & 87 & $135 / 80$ \\
\hline 45 & $1 \cdot 52$ & $16 \cdot 5$ & 3.05 & $3 \cdot 59$ & $4 \cdot 1$ & $8 \cdot 4$ & $5 \cdot 6$ & 84 & 67 & $140 / 90$ \\
\hline 20 & $1 \cdot 52$ & $18 \cdot 1$ & $3 \cdot 18$ & $3 \cdot 86$ & $4 \cdot 1$ & $7 \cdot 4$ & 4.9 & 72 & 67 & $120 / 80$ \\
\hline 15 & $1 \cdot 29$ & $18 \cdot 3$ & $3 \cdot 24$ & $3 \cdot 84$ & $2 \cdot 7$ & 9.0 & 7.0 & 86 & 81 & $130 / 80$ \\
\hline 25 & 1.65 & $18 \cdot 8$ & $3 \cdot 62$ & $4 \cdot 36$ & $4 \cdot 8$ & $12 \cdot 7$ & $7 \cdot 6$ & 72 & 105 & $110 / 70$ \\
\hline 25 & $1 \cdot 48$ & $19 \cdot 4$ & $3 \cdot 48$ & $4 \cdot 22$ & $4 \cdot 0$ & $10 \cdot 2$ & 6.9 & 76 & 91 & $118 / 60$ \\
\hline 30 & $1 \cdot 53$ & $20 \cdot 5$ & $3 \cdot 90$ & $4 \cdot 79$ & $4 \cdot 2$ & $7 \cdot 8$ & $5 \cdot 1$ & 72 & 71 & $100 / 60$ \\
\hline 50 & $1 \cdot 78$ & $21 \cdot 0$ & $4 \cdot 77$ & $5 \cdot 90$ & $5 \cdot 3$ & $11 \cdot 7$ & $6 \cdot 6$ & 76 & 87 & $110 / 70$ \\
\hline 18 & $1 \cdot 76$ & $21 \cdot 5$ & $4 \cdot 50$ & $5 \cdot 58$ & $5 \cdot 2$ & $11 \cdot 8$ & $6 \cdot 7$ & 84 & 80 & $140 / 90$ \\
\hline 25 & $1 \cdot 52$ & $21 \cdot 5$ & $4 \cdot 49$ & $5 \cdot 52$ & $4 \cdot 2$ & $8 \cdot 8$ & $4 \cdot 8$ & 90 & 65 & $130 / 85$ \\
\hline 25 & 1.87 & $22 \cdot 0$ & $4 \cdot 40$ & $5 \cdot 50$ & $5 \cdot 6$ & $8 \cdot 6$ & $4 \cdot 6$ & 66 & 70 & $125 / 65$ \\
\hline 17 & $1 \cdot 62$ & $22 \cdot 5$ & $3 \cdot 95$ & 4.97 & $4 \cdot 7$ & $5 \cdot 9$ & $3 \cdot 7$ & 50 & 74 & $115 / 60$ \\
\hline 25 & $1 \cdot 52$ & $23 \cdot 7$ & $3 \cdot 20$ & $4 \cdot 10$ & $4 \cdot 1$ & $6 \cdot 9$ & $4 \cdot 5$ & 78 & 58 & $115 / 55$ \\
\hline 15 & $1 \cdot 36$ & $25 \cdot 2$ & $2 \cdot 42$ & $3 \cdot 15$ & $3 \cdot 4$ & $7 \cdot 9$ & $5 \cdot 8$ & 84 & 69 & $110 / 60$ \\
\hline 20 & $1 \cdot 75$ & $25 \cdot 7$ & $4 \cdot 29$ & $5 \cdot 60$ & $5 \cdot 2$ & $6 \cdot 9$ & 3.9 & 58 & 68 & $115 / 70$ \\
\hline 19 & $1 \cdot 71$ & $26 \cdot 3$ & $3 \cdot 33$ & $4 \cdot 39$ & $5 \cdot 0$ & $7 \cdot 3$ & $4 \cdot 3$ & 70 & 61 & $130 / 70$ \\
\hline 28 & 1.67 & $26 \cdot 5$ & 3.55 & 4.68 & 4.9 & $7 \cdot 9$ & $4 \cdot 7$ & 68 & 69 & $105 / 50$ \\
\hline 40 & $1 \cdot 60$ & $27 \cdot 2$ & $3 \cdot 22$ & $4 \cdot 28$ & $4 \cdot 4$ & $11 \cdot 4$ & $7 \cdot 1$ & 90 & 79 & $130 / 80$ \\
\hline 19 & $1 \cdot 74$ & $27 \cdot 4$ & 3.97 & $5 \cdot 29$ & $5 \cdot 2$ & $11 \cdot 8$ & $6 \cdot 8$ & 68 & 100 & $125 / 65$ \\
\hline 60 & 1.61 & $27 \cdot 5$ & $3 \cdot 35$ & $4 \cdot 45$ & $4 \cdot 6$ & $5 \cdot 0$ & $3 \cdot 1$ & 60 & 52 & $120 / 70$ \\
\hline 19 & $1 \cdot 56$ & $28 \cdot 2$ & $2 \cdot 46$ & $3 \cdot 37$ & $4 \cdot 3$ & 6.0 & 3.9 & 66 & 59 & $115 / 60$ \\
\hline 28 & 1.68 & $30 \cdot 2$ & $4 \cdot 53$ & $6 \cdot 20$ & 4.9 & $7 \cdot 5$ & $4 \cdot 5$ & 58 & 77 & $130 / 70$ \\
\hline 19 & 1.66 & $30 \cdot 7$ & $3 \cdot 30$ & $4 \cdot 58$ & $4 \cdot 8$ & $7 \cdot 0$ & $4 \cdot 2$ & 76 & 56 & $110 / 70$ \\
\hline 17 & 1.55 & $31 \cdot 2$ & $2 \cdot 79$ & $3 \cdot 91$ & $4 \cdot 3$ & 6.9 & $4 \cdot 4$ & 74 & 60 & $120 / 60$ \\
\hline 18 & 1.67 & $31 \cdot 7$ & $3 \cdot 29$ & $4 \cdot 65$ & 4.9 & $12 \cdot 3$ & $7 \cdot 4$ & 116 & 64 & $130 / 80$ \\
\hline 18 & $1 \cdot 62$ & $32 \cdot 3$ & $3 \cdot 29$ & $4 \cdot 67$ & $4 \cdot 6$ & $12 \cdot 6$ & $7 \cdot 8$ & 76 & 102 & $110 / 70$ \\
\hline 20 & 1.63 & $34 \cdot 0$ & 3.00 & $4 \cdot 35$ & $4 \cdot 7$ & $6 \cdot 5$ & $4 \cdot 0$ & 68 & 59 & $130 / 80$ \\
\hline 20 & 1.60 & $34 \cdot 6$ & $2 \cdot 92$ & $4 \cdot 25$ & $4 \cdot 6$ & 3.9 & $2 \cdot 4$ & 54 & 45 & $130 / 70$ \\
\hline 30 & $1 \cdot 62$ & $34 \cdot 7$ & $2 \cdot 80$ & $4 \cdot 10$ & $4 \cdot 6$ & $5 \cdot 7$ & $3 \cdot 3$ & 68 & 49 & $120 / 70$ \\
\hline \multicolumn{11}{|c|}{ Healthy subjects } \\
\hline 21 & 1.65 & $44 \cdot 5$ & $2 \cdot 32$ & 3.90 & $4 \cdot 5$ & $5 \cdot 9$ & $3 \cdot 5$ & 75 & 47 & $120 / 95$ \\
\hline 22 & $1 \cdot 59$ & $50 \cdot 0$ & $2 \cdot 25$ & $4 \cdot 15$ & $4 \cdot 5$ & $5 \cdot 5$ & $3 \cdot 5$ & 86 & 41 & $112 / 88$ \\
\hline 30 & 1.90 & $45 \cdot 0$ & $3 \cdot 52$ & 5.95 & $5 \cdot 7$ & $8 \cdot 6$ & $4 \cdot 5$ & 76 & 59 & $130 / 80$ \\
\hline 18 & 1.69 & $42 \cdot 5$ & $2 \cdot 64$ & 4.31 & $4 \cdot 9$ & $7 \cdot 5$ & $4 \cdot 4$ & 80 & 55 & $115 / 70$ \\
\hline
\end{tabular}

globin was under $7 \mathrm{~g}$. $/ 100 \mathrm{ml}$, increased more with severe anæmia, accompanied by slight tachycardia. Sharpey-Schafer (1944) using the Fick method found that the cardiac output was increased in cases of acute and chronic anæmia: this was accompanied by tachycardia in 18 out of 21 cases. He suggested that in severe anæmia, minute oxygen supply was maintained by the following adjustments: increased cardiac output, increased removal of available oxygen from the blood, and reduction in blood volume which results in greater hæmoglobin concentration upon which the available $\mathrm{O}_{2}$ depends. In our cases the reduction in blood volume was very slight compared to the marked reduction in his cases where out of 11 cases with chronic anæmia 8 had a blood volume of less than 3 litres and 2 had a blood volume between 3 and 4 litres. Out of our 30 cases, there were only 8 with a blood volume less than 4 litres and none with a blood volume less than 3 litres. However the concentrated corpuscle-hæmoglobin method reported by McMichael et al. (1943) and used for the determination of the blood volume by this author is open to serious criticism. Table III shows that the cardiac output comes down after the improvement of anæmia, and that in cases where it was determined for three or four times there was a relationship between the P.C.V. and the 


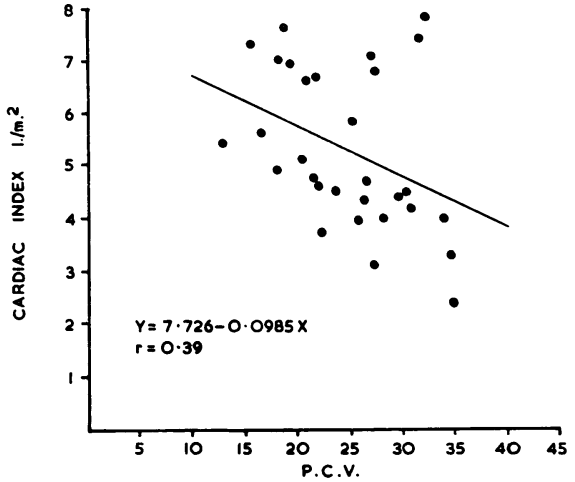

FIG. 2.-The correlation between cardiac index and packed cell volume in 30 cases of severe anæmia.

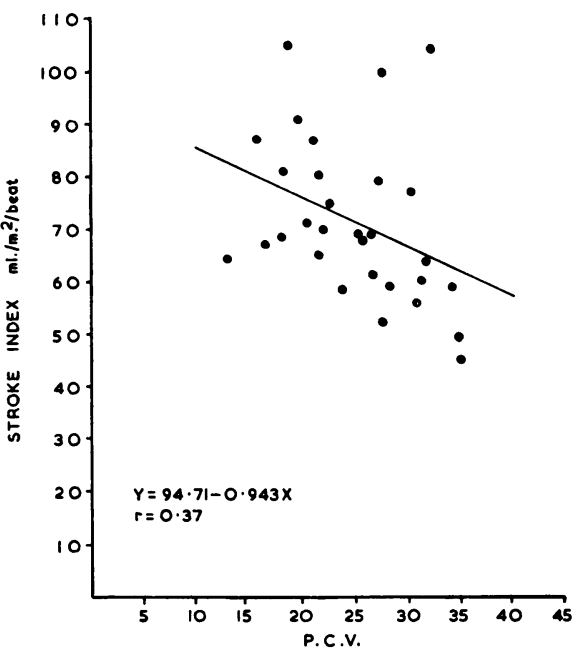

FIG. 3.- The correlation between stroke index and packed cell volume in 30 cases of severe anæmia.

TABLE III

Cardiac Output and Blood Volume Studies Repeated with the Improvement of anemia

\begin{tabular}{|c|c|c|c|c|c|c|c|c|c|c|}
\hline 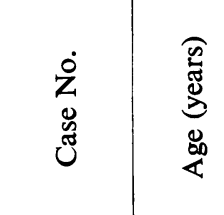 & 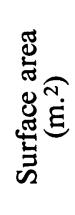 & $\begin{array}{l}\dot{0} \\
\dot{0}\end{array}$ & 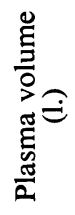 & 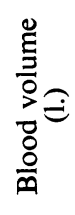 & 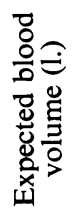 & 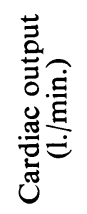 & 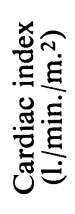 & 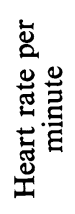 & 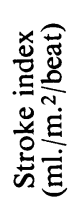 & 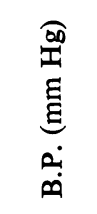 \\
\hline $\begin{array}{c}2 \\
\text { After } 28 \text { days: } \\
6 \\
\text { After } 35 \text { days: } 25 \\
11 \\
\text { After } 20 \text { days: } \\
16 \\
\text { After } 14 \text { days: } \\
23 \\
\text { After } 22 \text { days: } \\
29 \\
\text { After } 17 \text { days: } \\
8 \\
\text { After } 20 \text { days: } \\
\text { After } 20 \text { days: } \\
\text { After } 23 \text { days: } \\
18 \\
\text { After } 18 \text { days: } \\
\text { After } 19 \text { days: } \\
28 \\
\text { After } 17 \text { days: } \\
\text { After } 12 \text { days: } \\
32 \\
\text { After } 27 \text { days: } \\
\text { After } 46 \text { days: }\end{array}$ & $\begin{array}{l}1.60 \\
1.62 \\
1.67 \\
1.72 \\
1.67 \\
1.65 \\
1.67 \\
1.67 \\
1.52 \\
1.52 \\
1.29 \\
1.32 \\
1.53 \\
1.56 \\
1.56 \\
1.64 \\
1.76 \\
1.76 \\
1.80 \\
1.87 \\
1.90 \\
1.91 \\
1.48 \\
1.52 \\
1.52\end{array}$ & $\begin{array}{l}27 \cdot 2 \\
43 \cdot 2 \\
18 \cdot 8 \\
45 \cdot 6 \\
26 \cdot 5 \\
42 \cdot 5 \\
31 \cdot 7 \\
39 \cdot 7 \\
18 \cdot 1 \\
37 \cdot 5 \\
12 \cdot 9 \\
33 \cdot 0 \\
20 \cdot 5 \\
28 \cdot 0 \\
35 \cdot 2 \\
44 \cdot 2 \\
21 \cdot 5 \\
36 \cdot 3 \\
42 \cdot 5 \\
22 \cdot 0 \\
40 \cdot 5 \\
44 \cdot 0 \\
19 \cdot 4 \\
37 \cdot 0 \\
48 \cdot 2\end{array}$ & $\begin{array}{l}3 \cdot 22 \\
3 \cdot 05 \\
3 \cdot 62 \\
2 \cdot 93 \\
3 \cdot 55 \\
3 \cdot 27 \\
3 \cdot 29 \\
2 \cdot 97 \\
3 \cdot 18 \\
2 \cdot 86 \\
3.24 \\
2.95 \\
3.90 \\
3 \cdot 65 \\
3.20 \\
2 \cdot 92 \\
4 \cdot 50 \\
3.74 \\
3 \cdot 50 \\
4 \cdot 40 \\
3.95 \\
3.58 \\
3.48 \\
3.42 \\
2 \cdot 80\end{array}$ & $\begin{array}{l}4 \cdot 28 \\
4 \cdot 94 \\
4 \cdot 36 \\
5 \cdot 01 \\
4 \cdot 68 \\
5 \cdot 32 \\
4 \cdot 65 \\
4 \cdot 65 \\
3.86 \\
4 \cdot 35 \\
3 \cdot 65 \\
4 \cdot 21 \\
4 \cdot 79 \\
4.90 \\
4 \cdot 72 \\
4 \cdot 89 \\
5 \cdot 58 \\
5 \cdot 70 \\
5 \cdot 70 \\
5 \cdot 50 \\
6 \cdot 25 \\
6.00 \\
4 \cdot 22 \\
5 \cdot 15 \\
5 \cdot 05\end{array}$ & $\begin{array}{l}4 \cdot 4 \\
4 \cdot 4 \\
4 \cdot 85 \\
5 \cdot 0 \\
4 \cdot 85 \\
4 \cdot 8 \\
4 \cdot 85 \\
4 \cdot 85 \\
4 \cdot 1 \\
4 \cdot 1 \\
2 \cdot 7 \\
2 \cdot 9 \\
4 \cdot 2 \\
4 \cdot 3 \\
4 \cdot 3 \\
4 \cdot 8 \\
5 \cdot 2 \\
5 \cdot 2 \\
5 \cdot 4 \\
5 \cdot 6 \\
5 \cdot 7 \\
5 \cdot 7 \\
4 \cdot 0 \\
4 \cdot 2 \\
4 \cdot 2\end{array}$ & $\begin{array}{c}11 \cdot 4 \\
7 \cdot 1 \\
12 \cdot 75 \\
7 \cdot 3 \\
7 \cdot 9 \\
7 \cdot 3 \\
12 \cdot 3 \\
7 \cdot 0 \\
7 \cdot 4 \\
5 \cdot 8 \\
6 \cdot 9 \\
5 \cdot 8 \\
7 \cdot 8 \\
8 \cdot 4 \\
6 \cdot 5 \\
5 \cdot 87 \\
11 \cdot 8 \\
9 \cdot 2 \\
7 \cdot 5 \\
8 \cdot 6 \\
5 \cdot 95 \\
6 \cdot 15 \\
10 \cdot 2 \\
8 \cdot 15 \\
8 \cdot 2\end{array}$ & $\begin{array}{l}7 \cdot 1 \\
4 \cdot 4 \\
7 \cdot 6 \\
4 \cdot 75 \\
4 \cdot 7 \\
4 \cdot 4 \\
7 \cdot 4 \\
4 \cdot 2 \\
4 \cdot 9 \\
3 \cdot 8 \\
5 \cdot 4 \\
4 \cdot 4 \\
5 \cdot 1 \\
5 \cdot 4 \\
4 \cdot 2 \\
3 \cdot 57 \\
6 \cdot 7 \\
5 \cdot 2 \\
4 \cdot 15 \\
4 \cdot 6 \\
3 \cdot 13 \\
3 \cdot 2 \\
6 \cdot 9 \\
5 \cdot 35 \\
5 \cdot 4\end{array}$ & $\begin{array}{r}90 \\
65 \\
72 \\
75 \\
68 \\
66 \\
116 \\
110 \\
72 \\
76 \\
84 \\
72 \\
72 \\
84 \\
72 \\
76 \\
84 \\
80 \\
72 \\
66 \\
54 \\
60 \\
76 \\
68 \\
74\end{array}$ & $\begin{array}{r}79 \\
68 \\
105 \\
63 \\
69 \\
66 \\
64 \\
38 \\
67 \\
50 \\
64 \\
61 \\
71 \\
64 \\
58 \\
47 \\
80 \\
65 \\
58 \\
70 \\
58 \\
53 \\
91 \\
79 \\
72\end{array}$ & $\begin{array}{c}130 / 80 \\
130 / 80 \\
110 / 70 \\
125 / 75 \\
105 / 50 \\
120 / 80 \\
130 / 80 \\
130 / 80 \\
120 / 80 \\
120 / 70 \\
100 / 55 \\
90 / 60 \\
100 / 60 \\
120 / 80 \\
100 / 80 \\
140 / 90 \\
125 / 80 \\
140 / 90 \\
125 / 65 \\
120 / 85 \\
120 / 75 \\
118 / 60 \\
130 / 85 \\
125 / 85\end{array}$ \\
\hline
\end{tabular}


stroke index. It is clear from Tables II and III that the increase of cardiac output is not the result of increased heart rate or changes in the mean arterial pressure. Brannon et al. (1945) also found no changes in blood pressure. The simple conclusion that it is the result of reduced peripheral resistance as calculated from the formula, B.P. $=$ cardiac output times total peripheral resistance, lacks the experimental measurement of total peripheral resistance. However, many workers have calculated the peripheral resistance from the cardiac output and the blood pressure and later used these results to explain the changes in the cardiac output. The mean arterial pressure is the value generally used (Best and Taylor, 1961) but sometimes the systolic pressure is used (Barcroft et al., 1944).

Two explanations for the increased cardiac output make themselves apparent: increased heart size and more efficient emptying of blood from the ventricle.

The cardiac size was increased in three-quarters of the cases whether the frontal area was measured with the formula $A=\frac{\pi}{4}$ long $\times$ broad diameters, and compared with the expected area for the same height and weight, or the heart volume was measured by the methods already mentioned. The average heart volume was 780 and $764 \mathrm{ml}$. by the two methods, and was $484 \mathrm{ml}$. per square metre of surface area. The cardiac size decreased after the correction of anæmia. It is clear that, to a certain extent, a bigger heart can eject more blood.

Jalili (unpublished data) determined the cardiothoracic ratio in 122 cases of hookworm anæmia. The heart was enlarged in 56 per cent of 107 cases with a hæmoglobin of 40 per cent (Sahli) and less, not enlarged in 38, and border-line in 6 per cent. In another 15 cases with a hæmoglobin between 40 and 50 per cent (Sahli), the heart was enlarged in 4 cases only. However, when the radiological examination was repeated after the correction of anæmia the heart size became smaller in 25 of the 27 cases. In certain instances the heart became smaller although it was not originally enlarged according to this method of examination. Sanghvi, Misra, and Banerjee (1960), using the cardiothoracic ratio, found that the heart was enlarged in 80 per cent of 150 patients with severe anæmia, and returned to normal in 77 per cent; the remaining cases were considered to have hypertrophy of the heart. Porter (1937) also found increased heart size in cases of hookworm anæmia, sometimes with hypertrophy.

The stroke volume was found to be increased in exercise as one of the mechanisms of adaptation to exercise (Chapman et al., 1960): Liljestrand et al. (1938) found that it increased as a result of exercise from $44 \mathrm{ml}$. to $88 \mathrm{ml}$. in the sitting position. Adrenaline produced increased systolic ejection at the same mean filling pressure in the right atrium (McMichael and Sharpey-Schafer, 1944). A greater stroke volume can be attained solely through more complete systolic ejection (Nylin, 1943). In the recumbent position the average stroke volume was $71 \mathrm{ml}$. with a residual blood of $100 \mathrm{ml}$. per ventricle: these values were less in the standing position. Bing and Daley (1951) found that the average residual blood in the ventricle in the lying position was $89 \mathrm{ml}$. It seems to us that the stroke volume could be increased under certain conditions, and this may leave smaller residual blood in the ventricles. It is well known that training enables the heart to eject a larger amount of blood per beat (Asmussen and Nielsen, 1955); the stroke volume of normal adults varies during rest between 60 and $100 \mathrm{ml}$. depending on position. In our anæmic series it ranged in recumbent position between 72 and $176 \mathrm{ml}$. per beat with an average of $115 \mathrm{ml}$. in 19 cases and over $80 \mathrm{ml}$. in all cases except one who had a small heart by radiological examination.

There is no available physiological or pathological evidence that the heart in hookworm anæmia cannot to some extent perform well, and from personal unpublished studies heart failure does not develop unless the anæmia is extremely severe, except in older patients where heart failure occurs in moderately severe anæmia with a hæmoglobin of 4 to $5.5 \mathrm{~g} . / 100 \mathrm{ml}$. Neither was angina of effort observed. In experimental animals it was found that moderate anæmia did not lower the ventricular function curves significantly because of the increase in coronary blood flow, but in severe anæmia where the coronary dilatation could no longer compensate for the oxygen transport, there was depression of the ventricular function (Sarnoff, 1955; Case, Berglund, and Sarnoff, 1955).

It is clear from the review of Korner (1959) that in chronic anæmia the increase in cardiac output 
results chiefly from a rise in the stroke volume, and the mean arterial pressure is practically unaltered. The oxygen utilization increases from an average of 25 per cent with a normal arterial oxygen content of about $20 \mathrm{ml} . / 100 \mathrm{ml}$. to about $60-65$ per cent in severe anæmia with an oxygen content of $5 \mathrm{ml} . / 100 \mathrm{ml}$., with some individual variation related to the increase in cardiac output.

In the normal person, arterial blood contains about $200 \mathrm{ml}$. of oxygen per litre (allowing for temperature and pressure and assuming 95 per cent saturation). At a normal resting oxygen consumption of $250 \mathrm{ml}$. per minute and assuming a 100 per cent utilization of oxygen, the cardiac output cannot be less than $\frac{250}{200}=1.25$ litres per minute (cardiac index of $0.781 . / \mathrm{min} . / \mathrm{m} .{ }^{2}$ as the average surface area in our cases was $1.6 \mathrm{~m} .{ }^{2}$ ). If the body uses only 50 per cent of the arterial oxygen, then the cardiac output cannot be less than $2.51 . / \mathrm{min}$. (cardiac index of $1.561 . / \mathrm{min} . / \mathrm{m} .{ }^{2}$ ), and if the oxygen utilization is only 25 per cent, the cardiac output cannot be less than 5.01 ./min. (cardiac index $3 \cdot 12$ 1./min./m..$^{2}$ ). In Fig. 4 and 5 the cardiac index is plotted against the P.C.V. on a logarithmic scale.

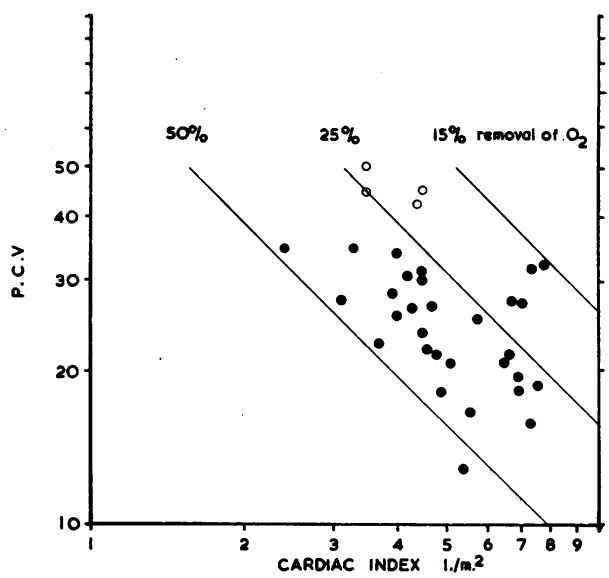

FIG. 4.-The cardiac index plotted against the packed cell volume on logarithmic scale with the theoretical zones of oxygen utilization. Dark points represent anæmic cases and open circles represent healthy subjects.

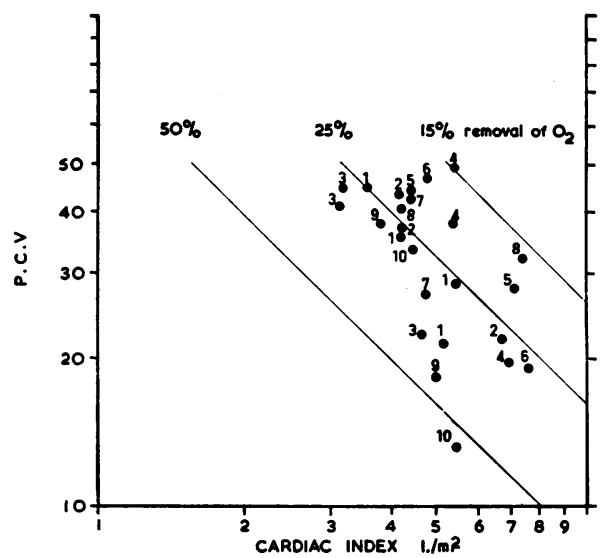

FIG. 5.-The cardiac index plotted against the packed cell volume on a logarithmic scale in 10 cases examined after treatment of the anæmia. Every case has an identifying number.

Three straight lines representing 50, 25, and 15 per cent utilization of oxygen are drawn. Fig. 4 suggests that the oxygen removal was between 25 and 50 per cent in the majority ( 25 of 30 cases): only in one case was it slightly higher. However, the conclusions of Sharpey-Schafer (1944) suggested a much higher oxygen removal, 80 to 90 per cent. Fig. 5 suggests that with the improvement of anæmia in 10 cases, the oxygen removal was reduced to a certain extent. The evidence points to a role played by increased oxygen removal from the blood in severe anæmia in the amelioration of tissue hypoxia.

The role of viscosity of the blood is not substantiated. Diminished viscosity was considered the cause of increased blood velocity and output in anæmia long ago (Fahr and Ronzone, 1922), but it was found later (Whittaker and Winton, 1933; Mendlowitz, 1948) that changes in blood viscosity are almost negligible and a change in P.C.V. from 15 to 40 per cent produced only a small increase in the viscosity of the blood.

\section{Mitral Regurgitation}

It is generally assumed that mitral regurgitation is present in cases of severe anæmia with cardiac enlargement and that this takes part in the production of cardiac murmurs so common in severe anæmia. Korner and Shillingford (1955) and Shillingford $(1958,1960)$ found that the dilution 
curve in mitral regurgitation was flattened, and a formula for the measurement of the regurgitation was proposed. This was confirmed by Woodward, Burchell, and Wood (1957), Monasteri and Donato (1958), and Carleton, Levinson, and Abelmann (1960). However it is clear from the present study that there is no flattening of the curves, which excludes the presence of appreciable

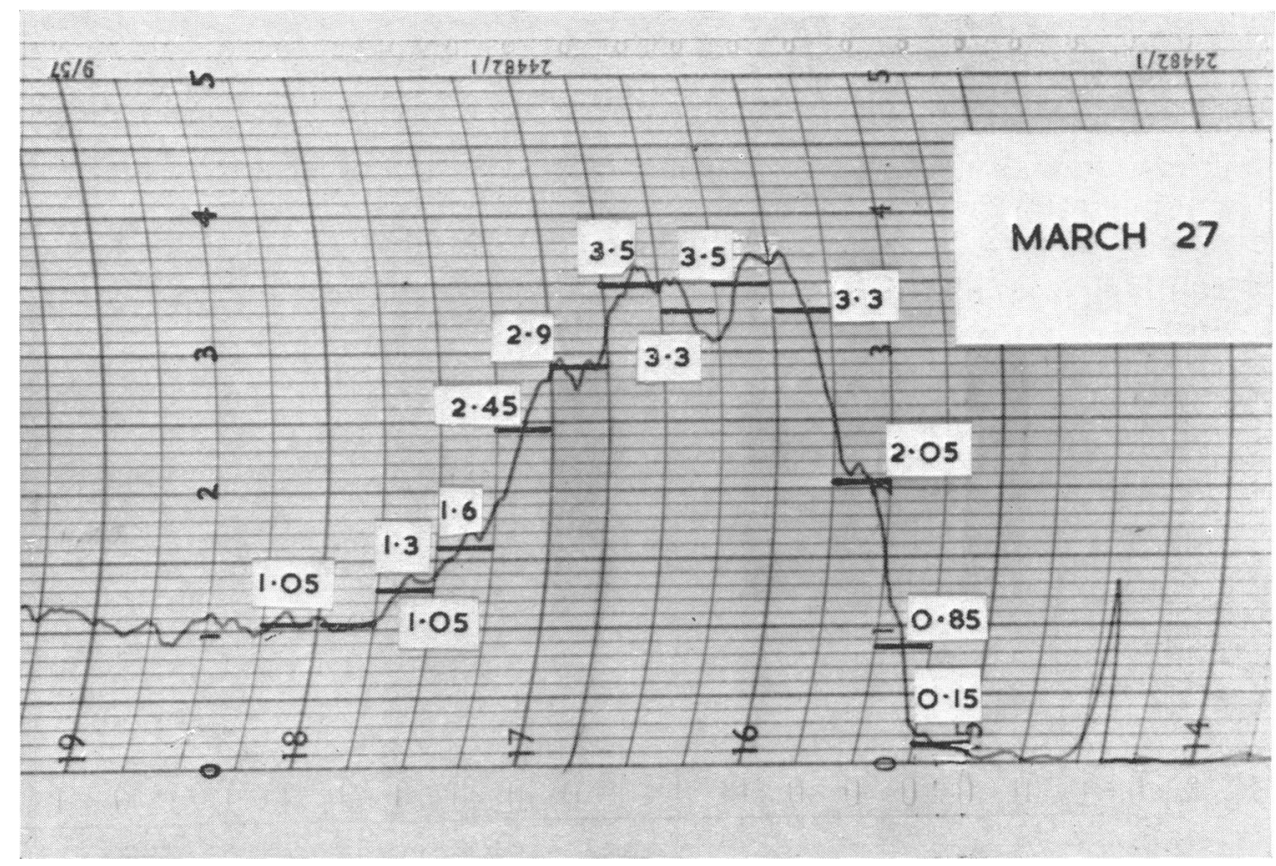

FIG. 6.-A dilution curve of a severely anæmic patient. It does not show the flattening reported in mitral regurgitation.

mitral regurgitation. Fig. 6 shows the curve of a patient with a cardiac index of $5.41 . / \mathrm{min} . / \mathrm{m} .{ }^{2}$ and a P.C.V. of 28 per cent and hæmoglobin of $5.6 \mathrm{~g} . / 100 \mathrm{ml}$. Fig. 1 shows the curve of the same patient when his P.C.V. was 44.2 per cent and his hæmoglobin $12.2 \mathrm{~g} . / 100 \mathrm{ml}$., and cardiac index 3.57 litres. This finding is of importance in the study of the conditon of the heart in anæmia with particular reference to enlargement and hæmic murmurs.

\section{SUMMARY}

The method for the determination of the cardiac output and blood volume using radio-iodinated human serum albumin and an external counting apparatus is described. The heart size was also determined radiologially. Thirty patients with hookworm anæmia and a hæmoglobin under $7 \mathrm{~g} .100 \mathrm{ml}$. and four healthy subjects were studied. In 10 patients this was repeated after treatment of the anæmia. The blood volume was slightly reduced in 62 per cent of them and was better related to the surface area: it increased after the correction of anæmia. The cardiac output was increased, and later decreased after the correction of anæmia. There was no tachycardia or appreciable change in the blood pressure. Increased heart size and better ejection of the blood were considered the probable underlying mechanisms. It is suggested that a moderate increase of oxygen utilization 0 plays some role in the amelioration of tissue hypoxia. Appreciable mitral regurgitation could not be demonstrated.

We wish to thank Mr. N. Veall for his help with the calculation methods. 


\section{REFERENCES}

Asmussen, E., and Nielsen, M. (1955). Physiol. Rev., 35, 778.

Barcroft, H., Edholm, O. G., McMichael, J., and Scharpey-Schafer, E. P. (1944). Lancet., 1, 489.

Berlin, N. I., Lawrence, J. H., and Gartland, J. (1950). J. Lab. clin. Med., 36, 435.

Best, C. H., and Taylor, N. B. (1961). The Physiological Basis of Medical Practice, 7th ed. Baillière, Tindall and Cox, London.

Biggam, A. G., and Ghalioungui, P. (1934). Lancet, 2, 299.

Bing, R. J., and Daley, R. (1951). Amer. J. Med., 10, 711.

Blacket, R. B., and Palmer, A. J. (1960). Brit. Heart J., 22, 483.

Bradley, S. E., Ingelfinger, F. J., Bradley, G. P., and Curry, J. J. (1945). J. clin. Invest., $24,890$.

Brannon, E. S., Merrill, A. J., Warren, J. V., and Stead, E. A., Jr. (1945). J. clin. Invest., $24,332$.

Brown, H. R., and Pearson, R. (1947). Proc. Soc. exp. Biol. (N.Y.), 65, 307.

Carleton, R. A., Levinson, G. E., and Abelmann, W. H. (1960). Amer. Heart J., 60, 396.

Case, R. B., Berglund, E., and Sarnoff, S. J. (1955). Amer. J. Med., 18, 397.

Chaplin, H., and Mollison, P. L. (1952). Blood, 7, 1227.

,-- , and Vetter, H. (1953). J. clin. Invest., 32, 1309.

Chapman, C. B., Fisher, J. N., and Sproule, B. J. (1960). J. clin. Invest., 39, 1208.

Cohn, J. E., and Shock, N. W. (1949). Amer. J. med. Sci., 217, 388.

Edwards, K. D. G., and Whyte, H. M. (1960). Clin. Sci., 19, 399.

Fahr, G., and Ronzone, E. (1922). Arch. intern. Med., 29, 331.

Feer, Y. van der, Douma, J. H., and Klip, W. (1958). Amer. Heart J., 56, 642.

Feldman, H. A., and Murphy, F. D. (1945). J. clin. Invest., 24, 780.

Fikri, M. M., and Ghalioungui, P. (1937). Lancet, 1, 800.

Gibson, J. G., and Evans, W. A., Jr. (1937). J. clin. Invest., 16, 317. , Harris, A. W., and Swigert, V. W. (1939). J. clin. Invest., 18, 621.

Gorlin, R., Brachfeld, N., Turner, J. D., Messer, J. V., and Salazar, E. (1959). J. clin. Invest., $38,2144$.

Gregersen, M. I. (1944). J. Lab. clin. med., 29, 1266. , and Rawson, R. A. (1959). Physiol. Rev., 39, 307.

Gunnells, J. C., and Gorten, R. (1961). J. appl. Physiol., 16, 261.

Huff, R. L., and Feller, D. D. (1956). J. clin. Invest., 35, 1.

-1, Judd, D. J., and Bogardus, G. M. (1955). Circulat. Res., 3, 564.

Inkley, S. R., Brooks, L., and Krieger, H. (1955). J. Lab. clin. Med., 45, 841.

Korner, P. I. (1959). Physiol. Rev., 39, 687.

, and Shillingford, J. P. (1955). Clin. Sci., 14, 553.

Liljestrand, G., Lysholm, E., and Nylin, G. (1938). Skand. Arch. Physiol., 80, 265, quoted by Asmussen and Nielsen (1955).

McMichael, J., and Sharpey-Schafer, E. P. (1944). Brit. Heart J., 6, 33.

- Mollison, P. L., and Vaughan, J. M. (1943). Lancet., 1, 637.

Mack, R. E., Wells, H. J., and Pollack, R. (1957). Radiology, 68, 245.

Mendlowitz, M. (1948). J. clin. Invest., 27, 565.

Monasterio, G., and Donato, L. (1958). Proceedings of the Second U.N. International Conference on the Peaceful Uses of Atomic Energy, vol. 26: Isotopes in Medicine, p. 83. U.N., Geneva.

Nylin, G. (1943). Amer. Heart J., 25, 598. (1957). Acta cardiol. (Brux.), 12, 588.

Perera, G. A. (1946). J. clin. Invest., 25, 401.

Porter, W. B. (1937). Amer. Heart J., 13, 550.

Pritchard, W. H., MacIntyre, W. J., and Moir, T. W. (1955). J. Lab. clin. Med., 46, 939.

Sanghvi, L. M., Misra, S. N., and Banerjee, K. (1960). Circulation, 22, 412.

Sarnoff, S. J. (1955). Physiol. Rev., 35, 107.

Schreiner, B. F., Lovejoy, F. W., and Yu, P. N. (1959). Circulat. Res., 7, 595.

Seldon, W. A., Hickie, J. B., and George, E. P. (1959). Brit. Heart J., 21, 401.

Shackman, R. (1958). Clin. Sci., 17, 317.

Sharpe, A. R., Jr., and Shapiro, W. (1961). Amer. Heart J., 61, 650.

Sharpey-Schafer, E. P. (1944). Clin. Sci., 5, 125.

Shillingford, J. (1958). Brit. Heart J., 20, 229.

(1960). In Proceedings of the Third European Congress of Cardiology, Rome, vol. 1 p. 133. Excerpta Medica, Amsterdam.

Starr, I., Donal, J. S., Margolies, A., Shaw, R., Collins, L. H., and Gamble, C. J. (1934). J. clin. Invest., $13,561$.

Storaasli, J. P., Krieger, H., Friedell, H. L., and Holden, W. D. (1950). Surg. Gynec. Obstet., $91,458$.

Taylor, H. L., Brozek, J., and Keys, A. (1952). J. clin. Invest., 31, 976.

, and Tiede, K. (1952). J. clin. Invest., 31, 209.

Ungerleider, H. E., and Gubner, R. (1942). Amer. Heart J., 24, 494.

Veall, N., Pearson, J. D., Hanley, T., and Lowe, A. E. (1954). In Radioisotope Conference 1954: Proceedings of the Second Conference, Oxford, vol. 1, p. 183. Butterworth, London.

- and Vetter, H. (1958). Radioisotope Techniques in Clinical Research and Diagnosis. Butterworth, London.

Whitby, L. E. H., and Britton, C. J. C. (1957). Disorders of the Blood, 8th ed., pp. 220, 226, 240, and 279. Churchill, London.

Whittaker, S. R. F., and Winton, F. R. (1933). J. Physiol. (Lond.), 78, 339.

Woodward, E., Burchell, H. B., and Wood, E. H. (1957). Proc. Mayo Clin., 32, 518.

Zipf, R. E., McGuire, T. F., Webber, J. M., and Grove, G. R. (1957). Amer. J. clin. Path., $28,134$. 